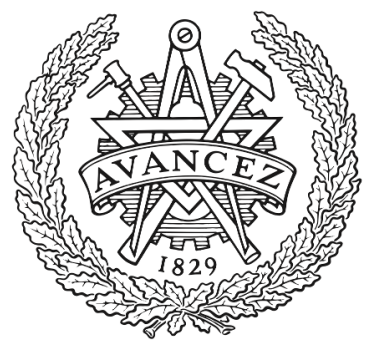

CHALMERS

UNIVERSITY OF TECHNOLOGY

\title{
Temperate fish community variation over seasons in relation to large-scale geographic seascape variables
}

Downloaded from: https://research.chalmers.se, 2023-04-26 14:47 UTC

Citation for the original published paper (version of record):

Perry, D., Staveley, T., Hammar, L. et al (2018). Temperate fish community variation over seasons in relation to large-scale geographic seascape variables. Canadian Journal of Fisheries and Aquatic Sciences, 75(10): 1723-1732. http://dx.doi.org/10.1139/cjfas-2017-0032

N.B. When citing this work, cite the original published paper. 


\title{
Temperate fish community variation over seasons in relation to large-scale geographic seascape variables
}

\author{
Diana Perry, Thomas A.B. Staveley, Linus Hammar, Alyssa Meyers, Regina Lindborg, \\ and Martin Gullström
}

\begin{abstract}
In shallow-water marine environments, ecosystem functioning is a complex interworking of fine-scale characteristics and region-wide factors, and the importance of these variables can vary on multiple temporal and spatial scales. This underwater video study targeted seasonal changes in the fish community of seagrass habitats along the Swedish west coast and the influence of offshore seascape variables (latitudinal position, wave exposure, open ocean, and deep water). Results showed that fish assemblage structure exhibited seasonal changes between summer and autumn and strong spatiotemporal variations in the importance of offshore factors affecting shallow-water fish communities. In summer, abundance from the Gobiidae family responded to wave exposure, whereas the Gadidae family and juvenile migrant habitat preference guild responded to latitudinal position and proximity to deep water. In autumn, deep water was related to abundance of Gadidae and juvenile migrants, whereas latitudinal position influenced Gasterosteidae. These findings underscore the importance of understanding the influence of offshore factors on facets of coastal fish assemblages to address large-scale geographic connectivity along nearshoreoffshore gradients.
\end{abstract}

Résumé : Dans les milieux marins de faible profondeur, le fonctionnement des écosystèmes repose sur les interactions complexes de caractéristiques à échelle fine et des facteurs d'ampleur régionale, et l'importance de ces variables peut varier à plusieurs échelles temporelles et spatiales. La présente étude basée sur la vidéo sous-marine s'intéresse aux changements saisonniers dans la communauté de poissons d'habitats d'herbier le long de la côte ouest de la Suède et à l'influence de variables du paysage marin extracôtier (latitude, exposition aux vagues, haute mer et milieux d'eau profonde). Les résultats montrent que la structure des assemblages de poissons présente des variations saisonnières entre l'été et l'automne, et ils font ressortir de fortes variations spatiotemporelles de l'influence de facteurs extracôtiers sur les communautés de poissons d'eau peu profonde. En été, l'abondance des gobiidés réagit à l'exposition aux vagues, alors que l'abondance des gadidés et de la guilde des migrants juvéniles en ce qui concerne les préférences d'habitats réagit à la latitude et à la proximité de milieux d'eau profonde. En automne, les milieux d'eau profonde sont reliés à l'abondance des gadidés et des migrants juvéniles, alors que la latitude influence les gastérostéidés. Ces constatations soulignent l'importance d'une bonne compréhension de l'influence des facteurs extracôtiers sur différentes facettes des assemblages de poissons côtiers pour comprendre la connectivité géographique à grande échelle le long de gradients entre les côtes et le large. [Traduit par la Rédaction]

\section{Introduction}

Fish are integrally linked to their environment, being influenced by both the biotic and the abiotic conditions surrounding them. In coastal waters, species-environment relationships can be remarkably complex, with patterns and processes influenced by both fine-scale single habitat variables (e.g., Jackson et al. 2006 a; Sirota and Hovel 2006; Gullström et al. 2008) and ocean-wide biogeochemical cycling (e.g., Humston et al. 2000; Comeau et al. 2002; Palumbi 2004; Caldwell and Gergel 2013; Reinke et al. 2016). Knowing that the coupling between nearshore and offshore areas is highly important for coastal dynamics and ecological stability (Estes et al. 1998; Able 2005), there is surprisingly little research explicitly addressing the influence of seascape-wide geographical settings on shallow-water fish communities. Understanding the strength of nearshore-offshore connectivity and the influence on shallow-water fish species is ecologically important and is becom- ing increasingly relevant for marine management as the climate is changing and further alterations are expected (Tuya et al. 2012; Reinke et al. 2016).

To understand how coastal ecosystems are linked to offshore environments, science must first understand the nearshore system and its natural variations. This includes the changes in assemblage structure of fish (and other mobile organisms) across seasons, which allows for an understanding of natural fluctuations over time. Such information is critical for distinguishing between expected changes and anomalous conditions, as can be expected with a changing environment and climate (Molinos et al. 2016). Much research has shown that fish assemblages vary over seasons, particularly in temperate coastal waters (e.g., Baden and Pihl 1984; Pihl and Wennhage 2002; Franco et al. 2006; Baden et al. 2012; Llompart et al. 2013), and it is therefore expected that different assemblages will respond and be influenced differently to the

Received 24 January 2017. Accepted 7 December 2017.

D. Perry, T.A.B. Staveley, and M. Gullström. Department of Ecology, Environment and Plant Sciences, Stockholm University, 10691 Stockholm, Sweden.

L. Hammar. Department of Energy and Environment, Chalmers University of Technology, 41296 Gothenburg, Sweden.

A. Meyers. Department of Veterinary Integrative Biosciences, Texas A\&M University, College Station, TX 77840, USA.

R. Lindborg. Department of Physical Geography, Stockholm University, 10691 Stockholm, Sweden.

Corresponding author: Diana Perry (email: diana.perry@su.se).

Copyright remains with the author(s) or their institution(s). This work is licensed under a Creative Commons Attribution 4.0 International License (CC BY 4.0), which permits unrestricted use, distribution, and reproduction in any medium, provided the original author(s) and source are credited. 
surrounding environment. Fish shift locations for various reasons, such as ontogenetic migrations, which may be associated with feeding, spawning, and (or) nursery areas, or seasonal environmental fluctuations. Therefore, it is important to understand how the influence of the surrounding seascape changes in relation to habitat preference shifts.

In the marine environment, many fish serve as mobile links between habitats or habitat patches and exchange biomass and energy across seascapes through their daily movements and migrations (Estes et al. 1998). For example, seagrass meadows in close proximity to other key habitats can increase fish densities in the area (Gullström et al. 2008; Berkström et al. 2013) and have a large influence on the fish assemblages because of their important role as nursery grounds for many juvenile fish (Heck et al. 2003). Although much effort has been made to understand seascape connectivity and the importance of surrounding nearshore habitat linkages to seagrass meadows in the last decade (e.g., Jackson et al. 2006a, 2006b; Gullström et al. 2008; Whitlow and Grabowski 2012; Berkström et al. 2013; Nagelkerken et al. 2015), little is known about the influence of the offshore-nearshore linkages and latitudinal gradients on seagrass fish assemblages. Furthermore, there is a substantial lack of studies examining the relative importance of regional-wide offshore seascape variables on distribution patterns of seagrass fish. Therefore, the rationale for this study is not to explicitly examine how small-scale nearshore factors influence seagrass-associated fish but, rather, to take a larger seascape perspective to create a first step in bridging the gap between the knowledge of the coastal systems and the surrounding offshore seascape.

For many marine fish, proximity to deep water has proven very important, as diurnal and seasonal migrations between shallow and deep habitats are frequent (Comeau et al. 2002; Strand and Huse 2007; Harvey et al. 2012) and because deep water upwelling is a source of nutrient-rich waters for shallow areas, increasing primary productivity (Madhupratap et al. 2001; Björk and Nordberg 2003; Lanari and Coutinho 2014; Davis et al. 2014). In temperate waters, upwelling can be of importance not only for the benefit of increasing primary production, but also for the reverse process of downwelling, which is critical for bringing oxygenated coastal water to the deep stagnant areas (Björk and Nordberg 2003). This is of particular relevance in coastal archipelagos and fjord systems along the Swedish west coast (Björk and Nordberg 2003). The archipelagos of the Swedish west coast are relatively sheltered and hydrodynamically less exposed environments, which are classified as water bodies separate from the outer coastal waters (Swedish Environmental Protection Agency 2008). In these sheltered areas, seagrass meadows grow on fine-grain substrate and can be heavily impacted by wave action caused by extreme weather events. Because fish species distributions are also dependent on interspecific interactions, changes in the ranges of individual species may have consequences for overall ecosystem functioning and structure (Albouy et al. 2013). By understanding how fish assemblages vary across latitudinal gradients, improved predictions can be made about current and future impacts of climate change within marine ecosystems (Tuya et al. 2012).

Due to the difficulty in assessing nearshore-offshore connectivity, given the multitude of factors involved in understanding such links, little research has focused on the topic thus far. In the present study, seagrass meadows were selected as the focal habitat due to their high importance for juvenile and subadult fish (Wennhage and Pihl 2002; Nagelkerken and van der Velde 2004; Gullström et al. 2008; Bertelli and Unsworth 2014; Staveley et al. 2017; Perry et al. 2018), and it stands to reason that seagrass meadows are intrinsically linked to the offshore seascape with fish communities influenced both by the local within-meadow processes and by the large-scale oceanographic and geographic factors. The aims of the current study were therefore to assess the influence of large-scale geographic seascape variables, specifically linking nearshore and offshore environments, on seagrassassociated fish assemblages during two productive seasons (summer and autumn). We hypothesized that fish assemblage characteristics would vary by season and posed the question of whether offshore variables (selected for their likeliness to change with a changing climate) influence the seagrass fish community and, if so, whether different families and fish guilds are affected differently. We predicted that migratory fish and habitat generalists would be affected by offshore variables, whereas stationary species would not be affected, as a result of their strong association with the coastal seagrass habitat. No previous assessments of large-scale geographic variables have been performed on seagrass fish communities in the area. Four geographic offshore seascape variables - i.e., geographical link to the open ocean, latitudinal position, distance to deep water $(\geq 20 \mathrm{~m})$, and wave exposure were selected for their anticipated relevance to fish communities and for their probability to be altered with a changing climate and sea level rise.

\section{Materials and methods}

\section{Study area}

The current study was conducted in seagrass (Zostera marina L.) meadows along the Swedish west coast $\left(58^{\circ} 00^{\prime} \mathrm{N}-58^{\circ} 55^{\prime} \mathrm{N}, 11^{\circ} 00^{\prime} \mathrm{E}-\right.$ $11^{\circ} 67^{\prime} \mathrm{E}$ ), in Skagerrak, spanning approximately $100 \mathrm{~km}$ of the coastline (Fig. 1). Seagrass meadows were selected because they are an important element of coastal waters in the region (Baden and Pihl 1984; Moksnes et al. 2008; Nyqvist et al. 2009; Gullström et al. 2012) that support a large diversity of juvenile and adult fish. The coastline is characterized by a complex archipelago with numerous islands and fjord-like inlets. The Skagerrak region is generally a productive transitional zone with saline water entering from the North Sea into the Skagerrak and connecting with the low-saline water from the southern Kattegat, influenced by the brackish waters of the Baltic Sea. The surface water salinity in the Skagerrak varies from 15 to 25 (Baden et al. 2012) and has been reported to be as much as 33 (Björk and Nordberg 2003). Though the area typically has very little tidal variation (mean, $0.3 \mathrm{~m}$ ), the water level can oscillate as much as $2 \mathrm{~m}$ depending on the strength of the winds (Johannesson 1989).

We examined 30 sites using a remote underwater stereo-video system (stereo-RUV) over two seasons, summer (June-July) and autumn (September-October) 2013, to assess fish assemblage compositions within seagrass meadows and to investigate the influence of large-scale geographic seascape variables. These seasons were selected because the fish abundance in seagrass meadows in the area has been shown to vary greatly between these seasons (Baden and Pihl 1984; Staveley et al. 2017; Gullström et al. unpublished data) and also because they cover the most productive parts of the year (e.g., seagrass habitats in the winter may be ice covered and hence are not included in this study). Given Sweden's northern latitude, there is a large variation in daylight hours, which drastically delineates these seasons, with an average daylight spanning from about $18 \mathrm{~h}$ in June and July to only $12 \mathrm{~h}$ in September and $10 \mathrm{~h}$ in October. However, salinity and sea temperature also vary between seasons and are important factors for fish populations. Unfortunately, the authors acknowledge a shortcoming of the sampling design in the current study due to the lack of site-specific salinity and sea temperature data collected. Due to this oversight, a general analysis was included in the supplementary material (Supplementary Table $S 1^{1}$ ) using weather station data from the middle of the $100 \mathrm{~km}$ study area.

${ }^{1}$ Supplementary data are available with the article through the journal Web site at http://nrcresearchpress.com/doi/suppl/10.1139/cjfas-2017-0032. 
Fig. 1. Map of study sites where cameras were placed. The map shows a zoomed image (top left) of one site overlain on the nautical chart where depth contours and the baseline are visible in relation to site location. Additionally, an image of the stereo-video camera setup is included (bottom left). Coastline: @Lantmäteriet I2016/00691; nautical chart: @ Swedish Maritime Administration. [Colour online.]

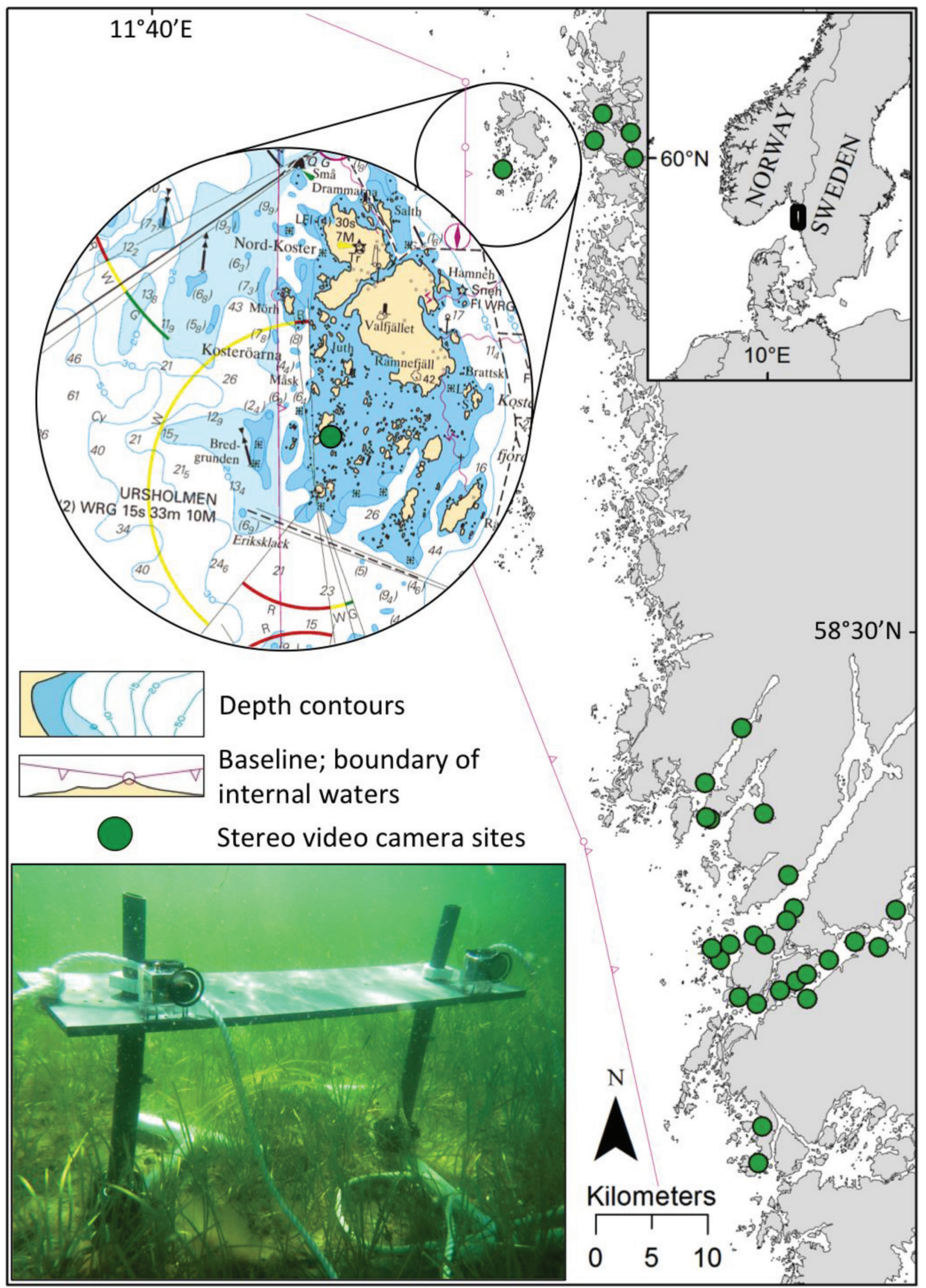


Each site was selected based on the quality of the seagrass, with each meadow's structural complexity comparable across sites (mean canopy height, $70 \pm 12.3 \mathrm{~cm}$; mean shoot density, $163 \pm$ 62.6 shoots $\mathrm{m}^{-2}$ ). Relative fish abundances for summer and autumn were analyzed via simple linear regression against seagrass height and density and no correlation was found; therefore, seagrass metrics were not included in further analysis. [Linear regression results: (i) summer abundance vs height $y=69.38-0.00 x$, $p=0.97, r^{2}=0.00$; vs density $y=170.22-0.02 x, p=0.54, r^{2}=0.01$ and (ii) autumn abundance vs height $y=69.81-0.00 x, p=0.85, r^{2}=0.00$; vs density $y=156.93+0.02 x, p=0.56 ; r^{2}=0.01$.] All locations were a minimum of $1500 \mathrm{~m}$ apart (with the exception of two sites that were within $600 \mathrm{~m}$ from one another but were separated by land and thus deemed to be independent in regard to fish communities).

\section{Camera surveys and fish classifications}

The stereo-RUV system was synchronized cameras recording the same object simultaneously (Mallet and Pelletier 2014), giving highly accurate, three-dimensional images; a method ideal for observing flora and fauna unobtrusively (Harvey et al. 2003). Given that the method allows the observer to collect data without disturbing the area, this becomes a valuable tool for studying mobile species such as fish. However, it is limited by visibility, requiring that the water is clear enough to observe speciesspecific characteristics of each specimen for identification.

For the present study, we used two GoPro HERO2 cameras mounted on a calibrated frame with $60 \mathrm{~cm}$ base separation. Specific calibration and set-up details are described in Hammar et al. (2013). The camera frame was deployed from a boat in a suitable and representative location within the seagrass meadows at depths ranging from approximately $1.8 \mathrm{~m}$ to $3.2 \mathrm{~m}$. The system was then checked via aquascope or by snorkeling to ensure that the cameras were unobstructed by seagrass and that there was a suitable recording field of view with the system angled slightly $\left(20^{\circ}\right)$ upwards to catch both the fish within the seagrass and some of the water column above the meadow. Once in position, the cameras were left alone, with the boat leaving the location and anchoring at a distance to be sure the fish in the area were not disturbed by researcher presence. Positional information for each camera site was recorded using GPS so that the same location could be re-located during the autumn field season. The field of view during all 60 recordings (30 sites and two seasons) ranged from approximately 0.3 to $3.5 \mathrm{~m}^{2}$, with two sites in the summer removed from the analysis due to poor visibility (summer visibility was slightly lower than autumn visibility, averaging $0.5 \mathrm{~m}^{2}$ and $0.9 \mathrm{~m}^{2}$, respectively). Camera deployment times were between 9:30 and 17:00 in the summer and between 9:00 and 15:30 in the autumn; due to the northern latitude of Sweden, summer and autumn sunset times are approximately 22:00 and 19:00, respectively.

After the cameras were deployed, recordings commenced for up to $80 \mathrm{~min}$ (depending on battery time). To ensure that analyzed fish were not disturbed, the first $5 \mathrm{~min}$, after the camera system was properly placed, were discarded and the following 60 consecutive minutes were analyzed. All video analyses were conducted by the same observer to guarantee the least variation in observer measurement and identification differences. This gave a total of $3480 \mathrm{~min}$ of analyzed film (1680 min from the summer season and $1800 \mathrm{~min}$ from the autumn season). Identification, quantification, and length measurements of fish were all computed and logged using the EventMeasure (www.seagis.com.au) software after the camera system had been calibrated. Length was only measured for fish that swam within the overlapping fields of view of both cameras (and therefore could be viewed in the two (stereo) images simultaneously). Given that individuals must be seen in both cameras, length measurements can be difficult to obtain if vegetation obstructs one field of view. This can, therefore, create a method- ological limitation by reducing the number of length-measurable fish compared with the number of identifiable individuals. However, when length measurements were obtained, adult and juvenile life stages were determined from their length at maturity, which were taken from FishBase (Froese and Pauly 2015). For species where specific maturity data were unavailable, individuals that were less than or equal to one-third of their maximum length (according to FishBase) were assumed to be juveniles (following Nagelkerken and van der Velde (2002)). We used the following response variables: total relative abundance from both seasons combined, total number of adult and juvenile fish, total number of species, the relative abundance of fish during each season of the five most frequently observed families (Gadidae, Gasterosteidae, Gobiidae, Labridae, and Syngnathidae), and the relative abundance of fish guilds based on habitat preference. Guilds are defined as a group of species utilizing the same habitats in similar ways. Here, we approximate the amount of fish as relative abundance for each site, defined as the number of times fish entered the recorded area, divided by the size of recorded area (and thus corrected for variation in visibility) divided by the time observed $(1 \mathrm{~h})$ (Hammar et al. 2015). Therefore, a relative abundance value is calculated for each site where the 30 sites then become the replicates. Also, species diversity was calculated using the ShannonWiener diversity index and compared between seasons.

In addition to life stage classification, all identified fish were further divided into guilds based on habitat preference (Table 1). This guild classification system was based on information put forth by Staveley et al. (2017) and Perry et al. (2018), as well as Elliott and DeWailly (1995), Pihl and Wennhage (2002), Pihl et al. (2006), and Froese and Pauly (2015). The groups of guilds were as follows: shallow-water generalists (SWG), occasional shallowwater visitors (OSV), juvenile migrants (JM), and stationary species (SS). Fish classified as SS are those that generally do not leave their habitat or habitat patch such as a seagrass meadow, SWG move regularly between shallow-water habitats (e.g., seagrass meadows and rocky bottoms) on a hundred metre scale, OSV fish move freely between various habitats on a kilometre scale, and JM are species found in seagrass meadows during their earlier life stages. The JM guild (taken from the literature) was based on species that rely on seagrass meadows in the early part of their lives and therefore was not determined from size information, whereas measurable fish, regardless of the species, could be classified as juveniles for life stage analyses. Note that individuals from the Pleuronectidae family were not included in the guild analysis because no individuals could be identified to species level and different species within this family have different habitat preferences (e.g., Platichthys flesus (Linnaeus, 1758) is a SWG, whereas Pleuronectes platessa Linnaeus, 1758 is a JM).

\section{Seascape predictor variables}

To understand the influence of seascape metrics on shallowwater seagrass fish assemblages, the fish survey data were analyzed in relation to the four selected seascape predictor variables, i.e., distance to the open ocean (Ocean), distance to the northern most latitudinal line (Lat), distance to deep water $>20 \mathrm{~m}$ (Deep), and wave exposure (WaveEx).

All seascapes and relevant distance measures were evaluated using ArcGIS 10.2. A nautical sea chart was used to determine the distance to open ocean (Fig. 1; baseline) where the nautical chart baseline demarcation was used as a proxy for the open ocean (Swedish Environmental Protection Agency 2008). According to the UN Convention of the Law of the Sea, the baseline follows the low-water line of a coastal state, and therefore, all water on the land side of the baseline is classified as coastal waters, whereas the water on the other side of the baseline mark constitutes open ocean. The nautical chart was also used to determine the distance to deep water using calculations to the nearest deep water point, equal to or greater than $20 \mathrm{~m}$ (selected on the basis that the 
Table 1. Results for fish families, as well as species, with associated habitat preference guilds.

\begin{tabular}{|c|c|c|c|c|c|c|c|}
\hline \multirow[b]{3}{*}{ Species } & \multirow[b]{3}{*}{ Guild } & \multicolumn{4}{|c|}{ Relative abundance $\left(\mathrm{m}^{-2} \mathrm{~h}^{-1}\right)$} & & \\
\hline & & \multicolumn{2}{|c|}{ Summer } & \multicolumn{2}{|c|}{ Autumn } & \multicolumn{2}{|c|}{ SIMPER analysis } \\
\hline & & Mean & SE & Mean & SE & DC\% & Rank \\
\hline Anguillidae & & 0.04 & 0.04 & 0.00 & 0.00 & & \\
\hline Anguilla anguilla & OSV & 0.04 & 0.04 & 0.00 & 0.00 & & \\
\hline Belonidae & & 0.04 & 0.04 & 0.14 & 0.14 & & \\
\hline Belone belone & OSV & 0.04 & 0.04 & 0.14 & 0.14 & & \\
\hline Clupeidae & & 0.17 & 0.12 & 0.33 & 0.22 & & \\
\hline Clupea harengus & OSV & 0.07 & 0.06 & 0.33 & 0.22 & & \\
\hline Gadidae & & 19.08 & 6.33 & 23.02 & 11.42 & & \\
\hline Gadus morhua & JM & 2.53 & 1.31 & 0.94 & 0.51 & & \\
\hline Merlangius merlangus & $\mathrm{M}$ & 4.70 & 2.94 & 12.03 & 8.05 & 4.01 & 9 \\
\hline Pollachius pollachius & JM & 0.63 & 0.57 & 0.75 & 0.35 & & \\
\hline Pollachius virens & JM & 4.04 & 2.17 & 4.03 & 2.28 & 3.88 & 10 \\
\hline Gadidae spp. & & 7.17 & 2.61 & 5.28 & 2.53 & 5.19 & 7 \\
\hline Gasterosteidae & & 76.72 & 34.54 & 57.39 & 18.50 & & \\
\hline $\begin{array}{l}\text { Gasterosteus } \\
\text { aculeatus }\end{array}$ & SWG & 76.39 & 34.56 & 54.59 & 18.59 & 11.44 & 2 \\
\hline Pungitius pungitius & OSV & 0.00 & 0.00 & 1.05 & 1.05 & & \\
\hline Spinachia spinachia & SWG & 0.33 & 0.18 & 1.66 & 0.67 & & \\
\hline Gobidae & & 144.98 & 60.19 & 294.40 & 64.37 & & \\
\hline Aphia minuta & SS & 17.23 & 5.91 & 0.12 & 0.12 & 4.66 & 8 \\
\hline Gobius niger & SWG & 0.15 & 0.10 & 0.14 & 0.14 & & \\
\hline Gobiusculus flavescens & SS & 82.90 & 32.75 & 282.92 & 65.22 & 27.57 & 1 \\
\hline Pomatoschistus spp. & SWG & 0.20 & 0.20 & 0.00 & 0.00 & 6.24 & 4 \\
\hline Labridae & & 18.92 & 6.56 & 58.77 & 19.57 & & \\
\hline Ctenolabrus rupestris & SWG & 17.73 & 6.47 & 7.91 & 2.31 & 5.60 & 6 \\
\hline Symphodus melops & SWG & 0.89 & 0.86 & 49.96 & 18.64 & 10.39 & 3 \\
\hline Labridae spp. & & 0.30 & 0.29 & 0.90 & 0.29 & 1.61 & 13 \\
\hline Pleuronectidae & & 0.04 & 0.04 & 0.12 & 0.12 & & \\
\hline Pleuronectidae spp. & & 0.04 & 0.04 & 0.12 & 0.12 & & \\
\hline Salmonidae & & 0.26 & 0.25 & 0.42 & 0.17 & & \\
\hline Salmo trutta & OSV & 0.26 & 0.25 & 0.42 & 0.17 & & \\
\hline Scombridae & & 0.81 & 0.78 & 0.00 & 0.00 & & \\
\hline Scomber scombrus & OSV & 0.81 & 0.78 & 0.00 & 0.00 & & \\
\hline Syngnathidae & & 6.49 & 1.63 & 13.52 & 7.43 & & \\
\hline Entelurus aequoreus & SWG & 0.00 & 0.00 & 0.56 & 0.56 & & \\
\hline Nerophis ophidion & SS & 0.20 & 0.20 & 0.26 & 0.14 & & \\
\hline Syngnathus acus & SWG & 0.20 & 0.20 & 0.00 & 0.00 & & \\
\hline Syngnathus typhle & SS & 3.40 & 1.05 & 10.70 & 6.63 & 3.03 & 11 \\
\hline Syngnathidae spp. & & 2.68 & 0.96 & 2.00 & 0.96 & 2.02 & 12 \\
\hline Unidentified & & 27.38 & 13.74 & 2.48 & 1.28 & 5.62 & 5 \\
\hline
\end{tabular}

Note: SWG, shallow-water generalists; OSV, occasional shallow-water visitors; JM, juvenile migrants; SS, stationary species. See Material and methods for detailed information about the different habitat preference guilds. Mean relative abundance $\left(\mathrm{m}^{-2} \mathrm{~h}^{-1}\right)$ for all species in both summer and autumn with standard error (SE) included. SIMPER analysis results are included for fish species (based on abundances) contributing (by \%) most to dissimilarities in assemblage structure between the summer and autumn seasons (cumulative limit of 91\%). The data are based on individual abundances, and where "spp." is included, it indicates individuals that could only be identified to the family level, not the summation of all species within the family. DC\%, percent contribution to total dissimilarity.

halocline is above this depth for the area). To calculate the distance to the $20 \mathrm{~m}$ deep water point (as there was no $20 \mathrm{~m}$ contour line at most sites on the nautical chart), the distance to the $10 \mathrm{~m}$ depth contour was calculated, as well as the distance to the nearest point with a depth $>20 \mathrm{~m}$ (i.e., an exact bathymetric measurement taken directly from the nautical chart). The difference in distance between these two points (i.e., the $10 \mathrm{~m}$ depth contour and the nearest point with a depth $>20 \mathrm{~m}$ ) was used to calculate a horizontal distance per metre and, subsequently, the distance to $20 \mathrm{~m}$ deduced. This calculation is an estimate of horizontal distance (following the sea surface) and does not precisely follow the sea floor; however, it yields a general gradient where actual bathymetry data are lacking. Distances to deep water were taken via the most direct route through the water (as the fish swims), whereas open ocean and latitude calculations were based on a direct linear distance measurement from the study site, not circumventing obstructing land masses (as the crow flies). Direct measurements (as the crow flies) were done, as the archipelago system in the area creates a multitude of potential different swimming routes for fish traveling north-south or to-from the open ocean.

The latitudinal factor, i.e., position in the north-south gradient, was calculated as in Gullström et al. (2012); here, the distance was calculated in kilometres to the northernmost latitudinal line in the study area $\left(59^{\circ} \mathrm{N}\right)$. The archipelago on the Swedish west coast creates rather large differences between the distance to deep water and distance to the open ocean, with sites inside the fjord-like inlets located very near deep water, though far from the open 
Fig. 2. Average relative abundance $\left(\mathrm{m}^{-2} \mathrm{~h}^{-1}\right)$ of fish in summer and autumn seasons for the five most abundant fish families identified. Standard error bars included.

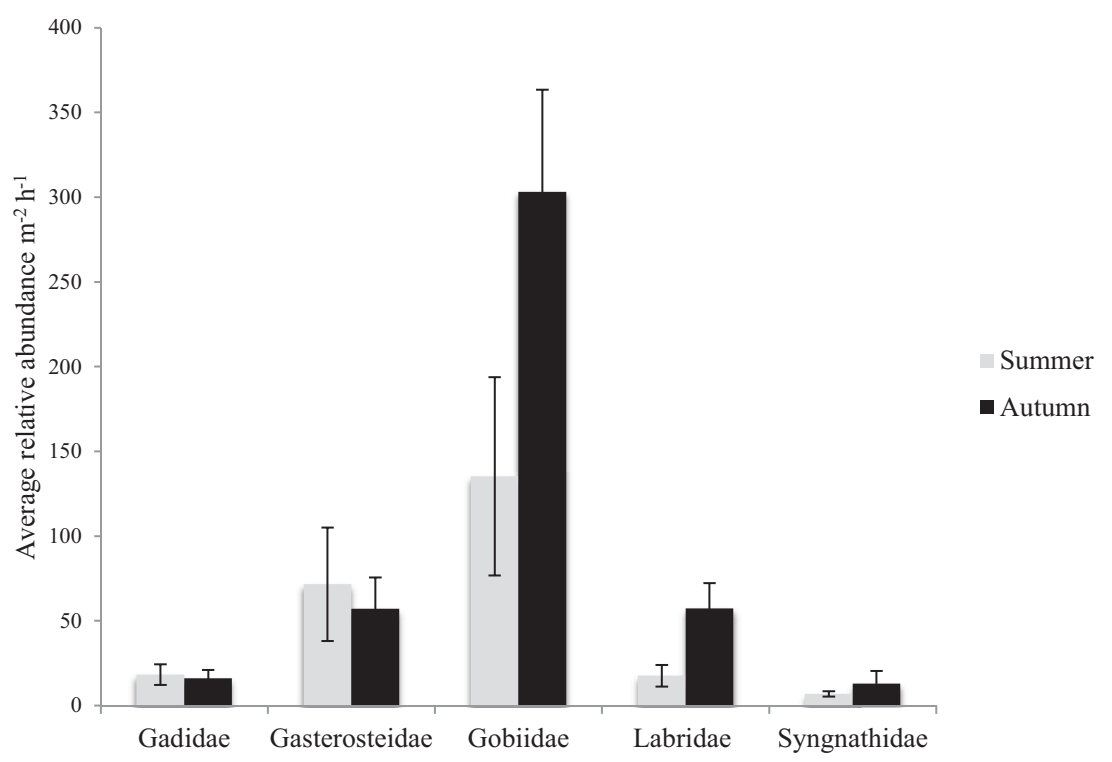

ocean (Fig. 1). Wave exposure measurements were determined using the commonly practiced method "effective fetch" calculating distance to land every $6^{\circ}$ for a total of 15 measurements per site, following Burrows et al. (2008), Gullström et al. (2012), and Aller et al. (2014), and were an assessment based on embayment exposure.

All predictor variables were selected on the premise that as climate change continues and the ocean properties are altered, the knowledge of the influence of these factors can aid in properly managing coastal waters. Understanding the current influence of such variables will allow for a better comprehension of their relative importance in the future.

\section{Statistical analysis}

Differences in total fish relative abundance (total number of species, total number of adults and juveniles) between seasons were analyzed by means of separate $t$ tests. The relative abundance between seasons was analyzed using a dependent $t$ test where each site in summer is compared with itself in the autumn, thereby identifying and excluding any within-group variation. Again, using the dependent $t$ test, Shannon-Wiener diversity index was compared between seasons. Additionally, we examined correlative relationships between seascape predictor variables (Ocean, Lat, Deep, and WaveEx) and seagrass fish variables (total species density, total number of species, and the density of different life stages, fish families, and habitat preference guilds) using non-parametric generalized linear models multiple regression analysis. We also investigated the influence of the distance to the outer coastline (as this is an archipelago and fjord system, this varies greatly for each site), but removed this as a predictor variable, as it was shown to be collinear with the distance to the open ocean (Ocean). All significant relationships between the predictors and response variables were graphed by scatterplots to determine positive or negative predictor influence. We assessed differences in fish assemblage structure between the autumn and summer seasons by performing non-parametric permutational multivariate analysis of variance (PERMANOVA) (Anderson 2001). Through canonical analysis of principal coordinates (CAP) patterns of similarities were visualized using constrained principal coordinate ordination (PCO) of a square-root transformed BrayCurtis similarity matrix to quantify and test relationships between fish assemblage structure (based on square-root transformed abundance data) and continuous seascape predictor vari- ables (based on $\log 10[x+1]$ transformed data) (Anderson and Willis 2003). The similarity of percentages (SIMPER) procedure was performed to determine the fish taxa contributing most to dissimilarities in assemblage structure between the two seasons.

\section{Results}

\section{Fish assemblages}

From all camera survey data, a total of 11409 fish, belonging to 22 species and 11 families, were counted from 58 videos recorded in the 30 study locations during both the summer and autumn seasons. Diversity, analyzed by means of the Shannon-Wiener diversity index, did not differ between summer and autumn $\left(t_{[27]}=0.08, p=0.94\right)$. Also, the total relative abundance between seasons did not differ significantly $\left(t_{[27]}=-1.25, p=0.22\right)$. Although the total number of species between seasons did not differ significantly, the assemblage structure of fish showed a clear separation between summer and autumn, which was confirmed by the PERMANOVA test $(p<0.001)$. The SIMPER analysis indicated that nearly $50 \%$ of the difference in assemblage structure between the summer and autumn seasons could be attributed to three species, namely Gobiusculus flavescens (Fabricius, 1779) from the Gobidae family (27.57\%), Gasterosteus aculeatus Linnaeus, 1758 from the Gasterosteidae family (11.44\%), and Symphodus melops (Linnaeus, 1758) from the Labridae family (10.39\%) (Table 1). Interestingly, similar relative abundance patterns were observed in the summer and autumn with the most abundant family being Gobiidae, followed by Gasterosteidae, Labridae, Gadidae, and finally, Syngnathidae (Fig. 2). However, in contrast to the summer, the autumn relative abundance doubled for Gobiidae $\left(135 \mathrm{~m}^{-2} \mathrm{~h}^{-1}\right.$ to $\left.303 \mathrm{~m}^{-2} \mathrm{~h}^{-1}\right)$, Labridae $\left(18 \mathrm{~m}^{-2} \mathrm{~h}^{-1}\right.$ to $\left.57 \mathrm{~m}^{-2} \mathrm{~h}^{-1}\right)$, and Syngnathidae $\left(7 \mathrm{~m}^{-2} \mathrm{~h}^{-1}\right.$ to $13 \mathrm{~m}^{-2} \mathrm{~h}^{-1}$ ), whereas it decreased slightly for both the Gadidae $\left(18 \mathrm{~m}^{-2} \mathrm{~h}^{-1}\right.$ to $\left.16 \mathrm{~m}^{-2} \mathrm{~h}^{-1}\right)$ and Gasterosteidae $\left(72 \mathrm{~m}^{-2} \mathrm{~h}^{-1}\right.$ to $\left.57 \mathrm{~m}^{-2} \mathrm{~h}^{-1}\right)$ families.

At the species level, the species seen with the highest frequency of occurrence in the summer were $G$. flavescens $(n=1433)$ from Gobiidae and G. aculeatus ( $n=589)$ from Gasterosteidae. Similarly, the same species were seen in the highest numbers in the autumn, though the numbers increased dramatically for $G$. flavescens ( $n=4826$ ) but dropped slightly for $G$. aculeatus $(n=486)$. In some cases, the frequency of occurrence of species differed considerably between summer and autumn. For instance, Aphia minuta (Risso, 1810) was identified on the videos 351 times in the summer 
Fig. 3. Average relative abundance $\left(\mathrm{m}^{-2} \mathrm{~h}^{-1}\right)$ of fish from different habitat preference guilds for the summer and autumn seasons. Standard error bars included.

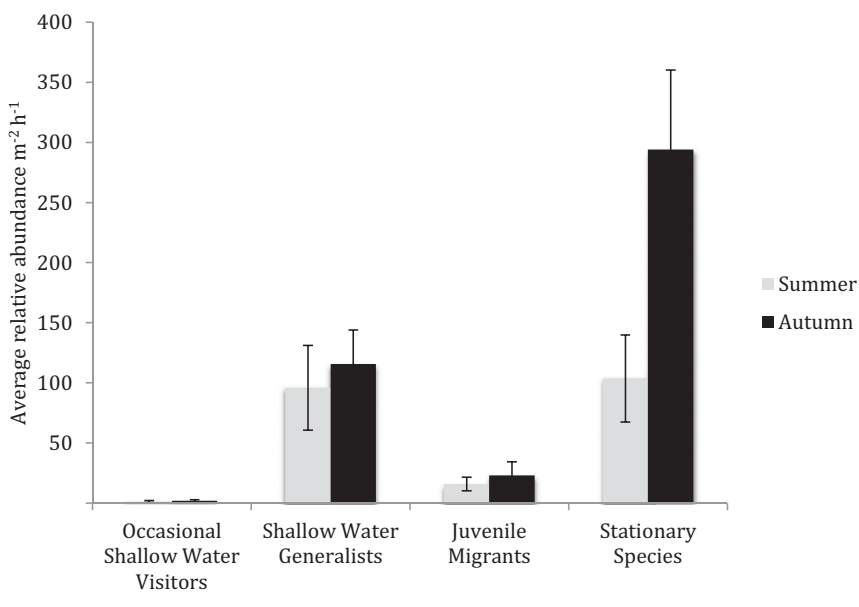

compared with only 2 times in the autumn, whereas Pungitius pungitius (Linnaeus, 1758) was not seen at all during the summer but was identified on 11 occasions in the autumn.

Of all measurable fish (those seen in both camera fields of view), the total relative abundance, seen over all videos, was comprised of $56 \%(n=152)$ juveniles during the summer season compared with $72 \%(n=515)$ juveniles in the autumn season. The total number of juveniles and adults did not differ significantly between seasons ( $p=0.16$ and $p=0.54$, respectively). For both the summer and autumn seasons, the greatest number of measureable individuals belonged to the Gadidae family. Gadid species such as Merlangius merlangus (Linnaeus, 1758) ( $n=43$, of which $53 \%$ were juveniles in the summer, to $n=172$, of which $53 \%$ were also juveniles in the autumn) and Pollachius virens (Linnaeus, 1758) $(n=173$, of which $30 \%$ were juveniles in the summer, to $n=276$, of which $79 \%$ were juveniles in the autumn) increased considerably from summer to autumn. Other species with a higher proportion of juveniles in the summer included $S$. melops $(0 \%$ to $82 \%)$ and Ctenolabrus rupestris (Linnaeus, 1758) (6\% to 29\%), both from the Labridae family.

The results for the habitat preference guilds showed that the guild with the highest relative abundance was from the SS group with fish from the Gobiidae and Syngnathidae families (Table 1) for both the summer and autumn seasons. The SWG guild, being the second most abundant, was only approximately one-half the abundance of SS for the autumn but nearly equal to the SS guild during the summer season (Fig. 3). The JM were found in low relative abundances, whereas OSV were nearly absent for both seasons (Fig. 3).

\section{Offshore seascape influence}

\section{Seasonal variation}

The offshore predictor variables WaveEx, Deep, and Lat were significantly related to the relative abundance of the seagrass fish community in the summer, grouped within family and habitat preference guilds (Table 2). Fish within the Gobiidae family were positively influenced by WaveEx, meaning that higher abundances were found in more exposed sites. The Gadidae family was also found to be positively influenced by proximity to deep water and northern latitudes, with the highest abundances found at sites farther north, as well as those closer to deep water. Additionally, fish within the habitat preference guild of JM had the same results, showing increased relative abundance in sites closer to deep water and in sites farther north.
Table 2. Generalized linear model multiple regression analysis ( $P$ values) for the relative abundance of fish family and habitat preference guild for the summer and autumn fish data and the seasonal data combined for life stage and total number of species and fish regressed against offshore predictor variables, namely Ocean, Lat, Deep, and WaveEx.

\begin{tabular}{|c|c|c|c|c|c|}
\hline & Ocean & Lat & Deep & WaveEx & $\begin{array}{l}\text { Overall } \\
\text { model }\end{array}$ \\
\hline \multicolumn{6}{|l|}{ Summer } \\
\hline \multicolumn{6}{|l|}{ Family } \\
\hline Gadidae & 0.694 & 0.003 & 0.041 & 0.195 & 0.000 \\
\hline Gasterosteidae & 0.889 & 0.952 & 0.213 & - & 0.986 \\
\hline Gobiidae & 0.841 & 0.142 & 0.335 & 0.043 & 0.233 \\
\hline Labridae & 0.205 & 0.435 & 0.125 & 0.899 & 0.007 \\
\hline Syngnathidae & 0.721 & 0.844 & 0.655 & 0549 & 0.009 \\
\hline \multicolumn{6}{|l|}{ Guild } \\
\hline OSV & - & - & - & - & 0.009 \\
\hline SWG & 0.970 & 0.981 & 0.520 & - & 0.992 \\
\hline JM & 0.694 & 0.003 & 0.041 & 0.195 & 0.000 \\
\hline SS & 0.883 & 0.210 & 0.344 & 0.107 & 0.180 \\
\hline \multicolumn{6}{|l|}{ Autumn } \\
\hline \multicolumn{6}{|l|}{ Family } \\
\hline Gadidae & 0.957 & 0.263 & 0.039 & 0.198 & 0.685 \\
\hline Gasterosteidae & 0.187 & 0.035 & 0.080 & 0.252 & 0.000 \\
\hline Gobiidae & 0.798 & 0.404 & 0.251 & 0.325 & 0.000 \\
\hline Labridae & 0.062 & 0.096 & 0.358 & 0417 & 0.006 \\
\hline Syngnathidae & 0.908 & 0.976 & 0.973 & 0.968 & 0.500 \\
\hline \multicolumn{6}{|l|}{ Guild } \\
\hline OSV & - & - & 0.787 & - & 0.884 \\
\hline SWG & 0.473 & 0.365 & 0.432 & 0.787 & 0.000 \\
\hline JM & 0.957 & 0.263 & 0.039 & 0.198 & 0.685 \\
\hline SS & 0.747 & 0.384 & 0.197 & 0.338 & 0.000 \\
\hline \multicolumn{6}{|c|}{ Seasons combined } \\
\hline \multicolumn{6}{|c|}{ Lifestage } \\
\hline Adult & 0.561 & 0.806 & 0.649 & 0.506 & 0.000 \\
\hline Juvenile & 0.955 & 0.428 & 0.147 & 0.281 & 0.000 \\
\hline \multicolumn{6}{|l|}{ Total } \\
\hline No. of species & 0.965 & 0.159 & 0.217 & 0.276 & 0.000 \\
\hline No. of fish & 0.547 & 0.033 & 0.853 & 0.543 & 0.000 \\
\hline
\end{tabular}

Note: Ocean, open ocean; Lat, latitudinal position; Deep, deep water $>20 \mathrm{~m}$; WaveEx, effective fetch. Significant correlations are shown in bold. Where there is a dash (-), no analysis results were possible for the model.

When examining the relative abundance of the fish from the autumn season compared with the summer season, the results partly cohere and partly differ (Table 2). Fish from the Gadidae family were negatively correlated with Deep, indicating that a closer proximity to deep water yielded higher abundances. The Gasterosteidae family were found in the highest abundances in the northern most study sites. At habitat preference guild level, there was a negative correlation between the relative abundance of the juvenile migrant (JM) guild and Deep, meaning that higher abundances were found closer to deep water (Table 2).

For the seasonal data combined, in relation to the life stage of the fish analyzed, no significant influence of offshore seascape predictor variables was found for either the relative abundance of adults or the relative abundance of juveniles. In addition, total number of species was not significantly influenced by the selected predictor variables (Table 2); however, the total number of observed fish were negatively correlated with Lat, yielding higher abundances in the northern most sites.

The constrained PCO indicates a clear separation in assemblage structure of fish species based on relative abundances between the summer and autumn seasons, as well as the degree to which the assemblages are influenced by the offshore predictor variables (Fig. 4). Figure 4 indicates an among-site similarity in fish assemblage structure in the autumn season, with most sites lacking any distinct influence by seascape predictors. The summer season, 
Fig. 4. Constrained principal coordinate ordination (PCO) of a square-root transformed Bray-Curtis similarity matrix. Objects that are ordinated closer together have higher similarity values than those ordinated further apart. Fish species assemblage data (based on relative abundances) are shown for the summer and autumn seasons. The first two axes account for 23.7\% (PCO1) and 18.7\% (PCO2) of the total variation, respectively.

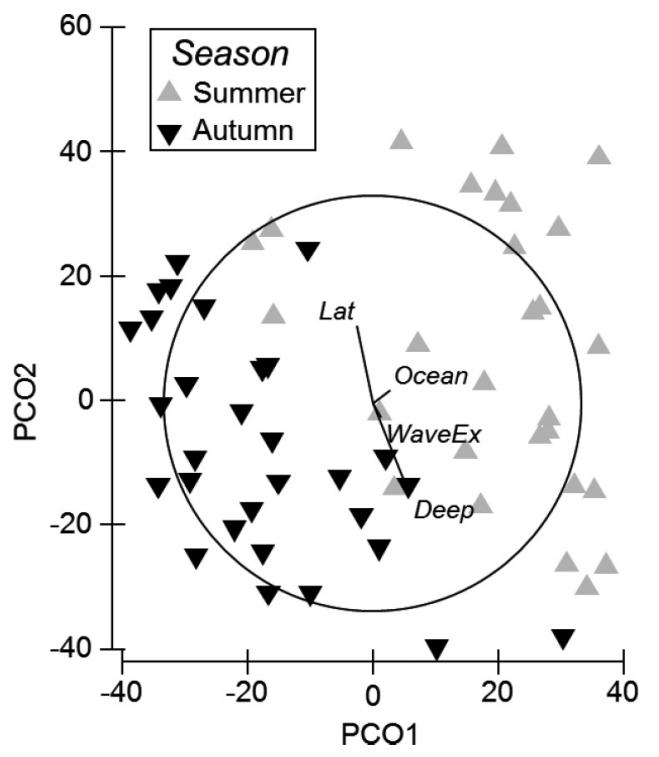

however, shows no discernable similarities in fish assemblage structure among sites. This figure represents the entire fish assemblage structure rather than specific families or guilds as described by the multiple linear regression results.

\section{Discussion}

The findings of this study indicate that seagrass-associated fish assemblage structure varies between summer and autumn seasons and that season-specific distribution patterns of different fish families and feeding preference guilds are related to geographic offshore seascape variables. As predicted, we found that fish with larger distribution ranges, and that are more migratory, were significantly correlated and, therefore, potentially influenced by several investigated offshore seascape variables. However, contrary to our predictions, the habitat generalist guild had no correlation with the predictor variables and one stationary fish family was in fact positively correlated with WaveEx. By understanding the changes in fish assemblages within seagrass meadows over seasons and then evaluating this information in regards to selected geographic variables related to the strength of nearshore-offshore coupling, this study attempts to take a first step in addressing large-scale geographic connectivity in this context.

From our results, we found that there is a clear difference in the fish assemblage structure between the summer and autumn seasons. This result is in keeping with other research on the Swedish west coast showing an obvious distinction in assemblage structure between seasons (Baden and Pihl 1984; Pihl and Wennhage 2002; Baden et al. 2012). For the current study, the difference between seasons was driven predominately by three species (of the 22 species observed throughout the study), including G. flavescens, $G$. aculeatus, and $S$. melops. All three species are relatively small (max length, $6 \mathrm{~cm}, 11 \mathrm{~cm}$, and $28 \mathrm{~cm}$, respectively) and confined to coastal shallow-water habitats (Froese and Pauly 2015). Their importance for the temporal variation seen in seagrass fish assemblage structure can be attributed to a shift in relative abundance between the seasons, with the relative abundance of both $G$. flavescens and $S$. melops increasing drastically in the autumn, whereas the relative abundance of $G$. aculeatus was higher in the summer than in the autumn.

Interestingly, though some of the studies showed similar overall patterns in abundances between the summer and the autumn, there were marked differences in the abundances of the species driving these changes. For instance, Baden et al. (2012) also found higher abundances of $G$. flavescens in the autumn; however, contrary to the current results, they also found a higher abundance of G. aculeatus in the autumn. Although there have been similar results regarding the increase in total relative abundance from summer to autumn (Baden and Pihl 1984; Staveley et al. 2017), another study has also shown the highest densities of fish in the summer as opposed to the autumn (Pihl and Wennhage 2002), which may be a result of sampling methods, different definitions of summer and autumn seasons (June and October), and (or) due to differences in number of sampling sites (with the earlier study surveying only three sites). This may also be a result of species-specific responses differing over years as a result of changes in weather or environmental conditions; however, given that the current study is limited by having only taken place over two seasons within the same year, it is difficult to be sure.

Given the differences observed in the fish assemblage structure between the two seasons, it is also highly relevant to assess the similarities and differences in the influence of examined offshorerelated geographic seascape variables. According to the results in the summer, the abundance of fish in the Gobiidae family appears to show a positive relationship with WaveEx, indicating that there is a preference for less sheltered sites. Many of the species within the Gobiidae family are stationary species showing high site fidelity, with research indicating that $G$. flavescens, the species with the highest relative abundance in the Gobiidae family in the current study, is associated with both macroalgae and seagrass habitats, using different parts of the water column during different life stages as a means of predator avoidance (Folkestad 2005). This result contradicted our hypothesis that offshore seascape variables would have little effect on stationary species and that increased wave exposure would be negative to these small fish due to high-energy output in these dynamic waters. A possible explanation is that $G$. flavescens is well adapted to water movements as it seeks prey in the shallow pelagic waters and that other gobies are typically bottom dwellers and thus less affected by hydrodynamics. Although it might be expected that the same pattern would also be seen in the autumn season, no such correlation occurs. This could be a result of the fact that G. flavescens (generally being the most abundant species in both seasons) was actually found to be of a smaller average size in the summer compared with the autumn (a pattern also seen in data from a concurrent study using beach seine sampling technique, where many more fish were able to be measured; Perry, D., Staveley, T.A.B., and Gullström, M., unpublished data). Increased water movement in more exposed sites could result in bringing larger numbers of juveniles to these areas, as has been observed with many species' larvae influenced by ocean currents (Christie et al. 2010; Petitgas et al. 2013). It has been shown that specimens of $G$. flavescens have larvae found in the sublittoral zone (Folkestad 2005), an area characterized by water flow. It was also shown that fish in the Gadidae family and JM habitat preference guild (a habitat preference guild comprised of fish mainly from the Gadidae family) had the highest abundances in the northern most study sites in the summer but not in the autumn. This is perhaps a result of the northern sites having a slightly earlier onset of summer light conditions and minimally higher temperatures (World Sea Temperature 2016 ) in the summer and also an earlier onset of shorter, darker days in the autumn. Additionally, the Gadidae family and JM guild were influenced by the proximity to deep water, with highest abundances found in sites closer to deep water. This deep-water association for Gadids and JM was also seen in the autumn, as they were positively associated with access to deep water near shallow- 
water habitats. Some species utilize both shallow- and deep-water habitats, and Atlantic cod, Gadus morhua Linnaeus, 1758, for instance, can make diel vertical migrations, as well as "chaotic" less regular migrations, between deep and shallow water (Strand and Huse 2007). Interestingly, Wennhage and Pihl (2002) found evidence of $G$. aculeatus, the species found in the highest relative abundance from the Gasterosteidae family, as a prey species in stomach content analysis of members of the Gadidae family from sites along the Swedish west coast. A plausible explanation then, for why this family shows a positive association with latitudinal position and is found in highest abundances in the northern most sites in the autumn (but not summer), is that this may be a direct response to predation. Here, we see that the Gadidae family and JM (comprised of mainly gadid species) were found in highest abundances in the northern sites in the summer while not in the autumn.

Rather interestingly, the current results also showed a positive association with the total relative abundance of fish from both seasons combined and latitudinal position, with the highest abundances seen in the northern most sites. It should be noted that the sites in the north are also the sites closest to Sweden's only national marine park, Kosterhavet, established in 2009. Though this was not studied directly, it cannot be ruled out that there may be a spillover park effect, which has been shown in other marine parks globally (McClanahan and Mangi 2000). However, the marine park allows various types of fishing throughout its boundaries, including trawling, and the park is likely to have little influence (Kosterhavet National Park 2009) on the northern sites, as most are more than $10 \mathrm{~km}$ away. It is therefore possible that shallow-water seagrass fish communities in Sweden are already experiencing northern range shifts as a result of increasing sea temperatures. As this study did not cover multiple years, no such conclusion can be made; however, further research into this topic would be of interest.

There is a strong coupling between the benthic and pelagic zones in shallow coastal waters, and for this reason, Kopp et al. (2015) emphasize the importance of understanding nearshoreoffshore dynamics to gain further knowledge of marine food webs and systems, such as the current study aimed to do. What we found from the results of the current study is that it requires evaluating specific community guilds and families to determine what impact regional-scale variables have on fish assemblages. As climate change continues to alter the oceans through increased temperatures leading to species range shifts and increased severe storm events, understanding the relationship of shallow-water ecosystems to large-scale seascape variables becomes even more important as these changes have implications for ecosystem connectivity at many spatial scales (Krosby et al. 2010). An investigation into effects of seascape structure and complexity on fish assemblages by Staveley et al. (2017) has shown that, at the same sites as this study, surrounding aspects of the seascape at a smaller scale than this study (i.e., on a $600 \mathrm{~m}$ scale) had influences upon the same seagrass fish community. Notably, some of the main results of the study by Staveley et al. (2017) showed smaller scale seascape influences on different aspects of the same fish community as this study. Mainly, their findings showed that juveniles in the summer, fish within the OSV guild in both the summer and autumn, and the Synganthidae family in the autumn all preferred less complex seascapes (e.g., larger areas of single habitats), whereas the Labridae family in the summer preferred more complex seascapes (e.g., areas with more smaller habitat patches) within the $600 \mathrm{~m}$ seascape. Rather interestingly, none of these aspects of the fish assemblage showed any significant influence of offshore factors in the current study, highlighting the importance of studying different aspects of the fish assemblage at a number of different scales. As such, certain aspects of a community can be influenced by the surrounding habitats on a smaller, more localized scale, whereas other aspects of the community may only be influenced by larger scale environmental factors. This demon- strates that, although smaller scale ecosystem variables may be extremely important for shaping various aspects of fish communities (Staveley et al. 2017; Jackson et al. 2006a, 2006b; Gullström et al. 2008, 2011; Berkström et al. 2013), it is imperative to maintain connectivity within shallow-water habitats and offshore areas (Dean et al. 2000; Kopp et al. 2015; Ramos et al. 2015), as well as across latitudinal gradients. Miyazono et al. (2010) found that specific species tend to differ with regard to dispersal ability, life history, and tolerance to environmental conditions and will therefore vary in their expected responses to future climatic changes.

Determining differences in responses among taxonomic groups, and the implications thereof, is an important step to ensure the possibility of a holistic ecosystem management approach. The current results indicate that the shallow-water fish assemblage structure is influenced by the offshore seascape environment and that the importance of the connection to the offshore variables changes with seasonal shifts. Additionally, the influence of the various seascape factors is fish family and (or) feeding guild dependent. Although this study is only an early contribution to the very complicated task of elucidating the myriad of offshore factors influencing shallow-water fish communities, it provides an initial, yet important, step in understanding the role of larger scale geographic variables on seagrass fish communities.

\section{Acknowledgements}

The authors thank the staff at the Sven Lovén Centre for Marine Sciences, Kristineberg (University of Gothenburg), for use of facilities and help with field work. Additionally, we thank Maria Asplund for her assistance, as well as for her generosity in loaning equipment. The authors extend their appreciation to the members of the Seagrass Ecology \& Physiology Research Group at DEEP (Department of Ecology, Environment and Plant Sciences), Stockholm University. The research was funded by The Swedish Research Council Formas (grant number, 2011-1640). The authors also extend their gratitude to two anonymous reviewers, as their comments greatly improved an earlier version of the manuscript.

\section{References}

Able, K.W. 2005. A re-examination of fish estuarine dependence: evidence for connectivity between estuarine and ocean habitats. Estuar. Coast Shelf Sci. 64: 5-17. doi:10.1016/j.ecss.2005.02.002.

Albouy, C., Guilhaumon, F., Leprieur, F., Lasram, F.B.R., Somot, S., Aznar, R., et al. 2013. Projected climate change and the changing biogeography of coastal Mediterranean fishes. J. Biogeogr. 40: 534-547. doi:10.1111/jbi.12013.

Aller, E., Gullström, M., Maarse, F., Gren, M., Nordlund, L.M., Jiddawi, N., and Eklöf, J.S. 2014. Single and joint effects of regional-and local-scale variables on tropical seagrass fish assemblages. Mar. Biol. 161: 2395-2405. doi:10.1007| s00227-014-2514-7.

Anderson, M.J. 2001. A new method for non-parametric multivariate analysis of variance. Austral Ecol. 26: 32-46. doi:10.1111/j.1442-9993.2001.01070.pp.x.

Anderson, M.J., and Willis, T.J. 2003. Canonical analysis of principal coordinates: a useful method of constrained ordination for ecology. Ecology, 84: 511-525. doi:10.1890/0012-9658(2003)084[0511:CAOPCA]2.0.CO;2.

Baden, S.P., and Pihl, L. 1984. Abundance, biomass and production of mobile epibenthic fauna in Zostera marina (L.) meadows, western Sweden. Ophelia, 23: 65-90. doi:10.1080/00785236.1984.10426605.

Baden, S., Emanuelsson, A., Pihl, L., Svensson, C., and Åberg, P. 2012. Shift in seagrass food web structure over decades is linked to overfishing. Mar. Ecol. Prog. Ser. 451: 61-73. doi:10.3354/meps09585.

Berkström, C., Lindborg, R., Thyresson, M., and Gullström, M. 2013. Assessing connectivity in a tropical embayment: fish migrations and seascape ecology. Biol. Conserv. 166: 43-53. doi:10.1016/j.biocon.2013.06.013.

Bertelli, C.M., and Unsworth, R.K.F. 2014. Protecting the hand that feeds us: Seagrass (Zostera marina) serves as commercial juvenile fish habitat. Mar. Pollut. Bull. 83: 425-429. doi:10.1016/j.marpolbul.2013.08.011.

Björk, G., and Nordberg, K. 2003. Upwelling along the Swedish west coast during the 20th century. Cont. Shelf Res. 23: 1143-1159. doi:10.1016/S0278-4343(03) 00081-5.

Burrows, M.T., Harvey, R., and Robb, L. 2008. Wave exposure indices from digital coastlines and the prediction of rocky shore community structure. Mar. Ecol. Prog. Ser. 353: 1-12. doi:10.3354/meps07284.

Caldwell, I.R., and Gergel, S.E. 2013. Thresholds in seascape connectivity: influence of mobility, habitat distribution, and current strength on fish movement. Landsc. Ecol. 28: 1937-1948. doi:10.1007/s10980-013-9930-9. 
Christie, M.R., Tissot, B.N., Albins, M.A., Beets, J.P., Jia, Y., Ortiz, D.M., et al. 2010. Larval connectivity in an effective network of marine protected areas. PLoS ONE, 5: e15715. doi:10.1371/journal.pone.0015715. PMID:21203576.

Comeau, L.A., Campana, S.E., and Castonguay, M. 2002. Automated monitoring of a large-scale cod (Gadus morhua) migration in the open sea. Can. J. Fish. Aquat. Sci. 59(12): 1845-1850. doi:10.1139/f02-152.

Davis, K.A., Banas, N.S., Giddings, S.N., Siedlecki, S., MacCready, P., Lessard, E.J., Kudela, R.M., and Hickey, B.M. 2014. Estuary-enhanced upwelling of marine nutrients fuels coastal productivity in the U.S. Pacific Northwest. J. Geophys. Res. Oceanogr. 119: 8778-8799. doi:10.1002/2014JC010248.

Dean, T.A., Haldorson, L., Laur, D.R., Jewett, S.C., and Blanchard, A. 2000. The distribution of nearshore fishes in kelp and eelgrass communities in Prince William Sound, Alaska: associations with vegetation and physical habitat characteristics. Environ. Biol. Fishes, 57: 271-287. doi:10.1023/A:1007652730085.

Elliott, M, and DeWailly, F. 1995. The structure and composition of European estuarine fish assemblages. Netherlands J. Aquat. Ecol. 29: 397-417. doi:10. 1007/BF02084239.

Environmental Protection Agency Sweden. 2008. Eutrophication of the seas along Sweden's West Coast.

Estes, J., Tinker, M., Williams, T., and Doak, D. 1998. Killer whale predation on sea otters linking oceanic and nearshore ecosystems. Science (80-), 282: 473476. doi:10.1126/science.282.5388.473.

Folkestad, H. 2005. Stage dependent habitat use under conflicting predation pressure: An experimental test with larval and juvenile two-spotted gobies, Gobiusculus flavescens Fabricius. J. Exp. Mar. Biol. Ecol. 323: 160-171. doi:10.1016| j.jembe.2005.04.005.

Franco, A., Franzoi, P., Malavasi, S., Riccato, F., and Torricelli, P. 2006. Fish assemblages in different shallow water habitats of the Venice Lagoon. Hydrobiologia, 555: 159-174. doi:10.1007/s10750-005-1113-5.

Froese, R., and Pauly, D. (Editors). 2015. FishBase. World Wide Web electronic publication, version (12/2016) www.fishbase.org.

Gullström, M., Bodin, M., Nilsson, P.G., and Öhman, M.C. 2008. Seagrass structural complexity and landscape configuration as determinants of tropical fish assemblage composition. Mar. Ecol. Prog. Ser. 363: 241-255. doi:10.3354/ meps07427.

Gullström, M., Berkström, C., Öhman, M.C., Bodin, M., and Dahlberg, M. 2011. Scale-dependent patterns of variability of a grazing parrotfish (Leptoscarus vaigiensis) in a tropical seagrass-dominated seascape. Mar. Biol. 158: 14831495. doi:10.1007/s00227-011-1665-z.

Gullström, M., Baden, S., and Lindegarth, M. 2012. Spatial patterns and environmental correlates in leaf-associated epifaunal assemblages of temperate seagrass (Zostera marina) meadows. Mar. Biol. 159: 413-425. doi:10.1007/s00227011-1819-z.

Hammar, L., Andersson, S., Eggertsen, L., Haglund, J., Gullström, M., Ehnberg, J., and Molander, S. 2013. Hydrokinetic turbine effects on fish swimming behaviour. PLoS ONE, 8: e84141. doi:10.1371/journal.pone.0084141. PMID:24358334.

Hammar, L., Eggertsen, L., Andersson, S., Ehnberg, J., Arvidsson, R., Gullström, M., and Molander, S. 2015. A probabilistic model for hydrokinetic turbine collision risks: exploring impacts on fish. PLoS ONE, 10: e0117756. doi:10.1371/journal.pone.0117756. PMID:25730314.

Harvey, E., Cappo, M., Shortis, M., Robson, S., Buchanan, J., and Speare, P. 2003. The accuracy and precision of underwater measurements of length and maximum body depth of southern bluefin tuna (Thunnus maccoyii) with a stereo-video camera system. Fish. Res. 63: 315-326. doi:10.1016/S01657836(03)00080-8.

Harvey, E.S., Butler, J.J., McLean, D.L., and Shand, J. 2012. Contrasting habitat use of diurnal and nocturnal fish assemblages in temperate Western Australia. J. Exp. Mar. Biol. Ecol. 426-427: 78-86. doi:10.1016/j.jembe.2012.05.019.

Heck, K.L., Hays, G., and Orth, R.J. 2003. Critical evaluation of the nursery role hypothesis for seagrass meadows. Mar. Ecol. Prog. Ser. 253: 123-136. doi:10. 3354/meps253123.

Humston, R., Ault, J.S., Lutcavage, M., and Olson, D.B. 2000. Schooling and migration of large pelagic fishes relative to environmental cues. Fish. Oceanogr. 9: 136-146. doi:10.1046/j.1365-2419.2000.00132.x.

Jackson, E.L., Attrill, M.J., and Jones, M.B. 2006a. Habitat characteristics and spatial arrangement affecting the diversity of fish and decapod assemblages of seagrass (Zostera marina) beds around the coast of Jersey (English Channel). Estuar. Coastal Shelf Sci. 68: 421-432. doi:10.1016/j.ecss.2006.01.024.

Jackson, E.L., Attrill, M.J., Rowden, A.A., and Jones, M.B. 2006b. Seagrass complexity hierarchies: influence on fish groups around the coast of Jersey (English Channel). J. Exp. Mar. Biol. Ecol. 330: 38-54. doi:10.1016/j.jembe.2005.12.016.

Johannesson, K. 1989. The bare zone of Swedish rocky shores: why is it there? Oikos, 54: 77-86. doi:10.2307/3565899.

Kopp, D., Lefebvre, S., Cachera, M., Villanueva, M.C., and Ernande, B. 2015. Reorganization of a marine trophic network along an inshore-offshore gradient due to stronger pelagic-benthic coupling in coastal areas. Prog. Oceanogr. 130: 157-171. doi:10.1016/j.pocean.2014.11.001.

Kosterhavet National Park. 2009. Kosterhavet National Park: A summary of resolutions-management plan-regulations.

Krosby, M., Tewksbury, J., Haddad, N.M., and Hoekstra, J. 2010. Ecological connectivity for a changing climate. Conserv. Biol. 24: 1686-1689. doi:10.1111/j. 1523-1739.2010.01585.x. PMID:20961330.

Lanari, M.D.O., and Coutinho, R. 2014. Reciprocal causality between marine macroalgal diversity and productivity in an upwelling area. Oikos, 123: 630640. doi:10.1111/j.1600-0706.2013.00952.x.

Llompart, F.M., Calautti, D.C., Cruz-Jimenez, A.M., and Baigun, C.R. 2013. Seasonal pattern of the coastal fish assemblage in Anegada Bay, Argentina. J. Mar. Biol. Assoc. U.K. 93: 2273-2285. doi:10.1017/S0025315413001045.

Madhupratap, M., Nair, K.N.V., Gopalakrishnan, T.C., Haridas, P., Nair, K.K.C., Venugopal, P., and Gauns, M. 2001. Arabian Sea oceanography and fisheries of the west coast of India. Curr. Sci. 81: 355-361.

Mallet, D., and Pelletier, D. 2014. Underwater video techniques for observing coastal marine biodiversity: a review of sixty years of publications (19522012). Fish. Res. 154: 44-62. doi:10.1016/j.fishres.2014.01.019.

McClanahan, T.R., and Mangi, S. 2000. Spillover of exploitable fishes from a marine park and its effect on the adjacent fishery. Ecol. Appl. 10: 1792-1805. doi:10.1890/1051-0761(2000)010[1792:SOEFFA]2.0.CO;2.

Miyazono, S., Aycock, J.N., Miranda, L.E., and Tietjen, T.E. 2010. Assemblage patterns of fish functional groups relative to habitat connectivity and conditions in floodplain lakes. Ecol. Freshw. Fish, 19: 578-585. doi:10.1111/j.16000633.2010.00438.x.

Moksnes, P., Gullström, M., Tryman, K., and Baden, S. 2008. Trophic cascades in a temperate seagrass community. Oikos, 117: 763-777. doi:10.1111/j.0030-1299. 2008.16521.x.

Molinos, J.G., Halpern, B.S., Schoeman, D.S., Brown, C.J., Kiessling, W., Moore, P.J., et al. 2016. Climate velocity and the future global redistribution of marine biodiversity. Nat. Clim. Change, 6: 83-88. doi:10.1038/NCLIMATE2769.

Nagelkerken, A.I., and van der Velde, G. 2002. Do non-estuarine mangroves harbour higher densities of juvenile fish than adjacent shallow water and coral reef habitats in Curacao (Netherlands Antilles)? Mar. Ecol. Prog. Ser. 245: 191-204. doi:10.3354/meps245191.

Nagelkerken, I., and van der Velde, G. 2004. A comparison of fish communities of subtidal seagrass beds and sandy seabeds in 13 marine embayments of a Caribbean island, based on species, families, size distribution and functional groups. J. Sea Res. 52: 127-147. doi:10.1016/j.seares.2003.11.002.

Nagelkerken, I., Sheaves, M., Baker, R., and Connolly, R.M. 2015. The seascape nursery: a novel spatial approach to identify and manage nurseries for coastal marine fauna. Fish Fish. 16: 362-371. doi:10.1111/faf.12057.

Nyqvist, A., André, C., Gullström, M., Baden, S.P., and Åberg, P. 2009. Dynamics of seagrass meadows on the Swedish Skagerrak coast. Ambio, 38: 85-88. doi:10.1579/0044-7447-38.2.85. PMID:19431937.

Palumbi, S.R. 2004. Marine reserves and ocean neighborhoods: the spatial scale of marine populations and their management. Annu. Rev. Environ. Resour. 29: 31-68. doi:10.1146/annurev.energy.29.062403.102254.

Perry, D., Staveley, T.A.B., and Gullström, M. 2018. Habitat connectivity of fish in temperate shallow-water seascapes. Front. Mar. Sci. 4: 1-12. doi:10.3389/ fmars.2017.00440.

Petitgas, P., Rijnsdorp, A.D., Dickey-Collas, M., Engelhard, G.H., Peck, M.A., Pinnegar, J.K., Drinkwater, K., Huret, M., and Nash, R.D.M. 2013. Impacts of climate change on the complex life cycles of fish. Fish. Oceanogr. 22:121-139. doi:10.1111/fog.12010.

Pihl, L., and Wennhage, H. 2002. Structure and diversity of fish assemblages on rocky and soft bottom shores on the Swedish west coast. J. Fish Biol. 61: 148-166. doi:10.1111/j.1095-8649.2002.tb01768.x.

Pihl, L., Baden, S., Kautsky, N., Rönnbäck, P., Söderqvist, T., and Wennhage, H. 2006. Shift in fish assemblage structure due to loss of seagrass Zostera marina habitats in Sweden. Estuar. Coastal Shelf Sci. 67: 123-132. doi:10.1016/j.ecss. 2005.10.016.

Ramos, D.A.E., Aragones, L.V., and Rollon, R.N. 2015. Linking integrity of coastal habitats and fisheries yield in the Mantalip reef system. Ocean Coastal Manage. 111: 62-71. doi:10.1016/j.ocecoaman.2015.04.009.

Reinke, J., Lemckert, C., and Meynecke, J. 2016. Coastal fronts utilized by migrating humpback whales, Megaptera novaeangliae, on the Gold Coast, Australia. J. Coastal Res. 75: 552-556. doi:10.2112/SI75-111.1.

Sirota, L., and Hovel, K. 2006. Simulated eelgrass Zostera marina structural complexity: effects of shoot length, shoot density, and surface area on the epifaunal community of San Diego Bay, California, USA. Mar. Ecol. Prog. Ser. 326: 115-131. doi:10.3354/meps326115.

Staveley, T.A.B., Perry, D., Lindborg, R., and Gullström, M. 2017. Seascape structure and complexity influence temperate seagrass fish assemblage composition. Ecography, 40: 936-946. doi:10.1111/ecog.02745.

Strand, E., and Huse, G. 2007. Vertical migration in adult Atlantic cod (Gadus morhua). Can. J. Fish. Aquat. Sci. 64(12): 1747-1760. doi:10.1139/f07-135.

Tuya, F., Cacabelos, E., Duarte, P., Jacinto, D., Castro, J., Silva, T., Bertocci, I., Franco, J., Arenas, F., Coca, J., and Wernberg, T. 2012. Patterns of landscape and assemblage structure along a latitudinal gradient in ocean climate. Mar. Ecol. Prog. Ser. 466: 9-19. doi:10.3354/meps09941.

Wennhage, H., and Pihl, L. 2002. Fish feeding guilds in shallow rocky and soft bottom areas on the Swedish west coast. J. Fish Biol. 61: 207-228. doi:10.1006/ jfbi.2002.2078.

Whitlow, W.L., and Grabowski, J.H. 2012. Examining how landscapes influence benthic community assemblages in seagrass and mudflat habitats in southern Maine. J. Exp. Mar. Biol. Ecol. 411: 1-6. doi:10.1016/j.jembe.2011.10.024.

World Sea Temperature. 2016 @. https://www.seatemperature.org/ [accessed 16 December 2016]. 